\title{
The Effect of Some Micro-Elements on Free Amino Acids, Indols and total Phenols Production from Embryogenic Callus of Tow Date Palm Cultivars (Sakkoty and Bartamuda)
}

\author{
1,a* Sherif F. El sharabasy, ${ }^{1}$ Abdel-Aal W. B., ${ }^{2}$ Hussein A.Bosila, \\ ${ }^{1}$ Abdel-Monem A. Bana and ${ }^{2}$ Bayome M. Mansour \\ ${ }^{1}$ The Central Lab of Date Palm Researches and Development, ARC, Giza, Egypt \\ ${ }^{2}$ Floriculture, Medicina I\& Aromatic Plants. Dept., Fac. of Agric., Al-Azhar University, Cairo Egypt \\ asharabasydates@yahoo.com
}

Keywords: microelements, manganese sulfate $\left(\mathrm{MnSO}_{4} 2 \mathrm{H} 2 \mathrm{O}\right)$, zinc sulfate $\left(\mathrm{ZnSO}_{4} 7 \mathrm{H} 2 \mathrm{O}\right)$, copper sulfate $\left(\mathrm{CuSO}_{4} 5 \mathrm{H} 2 \mathrm{O}\right)$, amino acids, phenols, indols, embryogenic callus, date palm

\begin{abstract}
Effect of microelements on some chemicals analysis of secondry metabolits such as free amino acids, total indols content and total phenols content of date palm cultivars (Sakkoty and Bartamuda) were study in this work. Different concentrations of manganese sulfate $\left(\mathrm{MnSO}_{4}\right.$ $2 \mathrm{H} 2 \mathrm{O})(22.3,44.6$ and $66.9 \mathrm{mg} / \mathrm{l})$, zinc sulfate $\left(\mathrm{ZnSO}_{4} 7 \mathrm{H} 2 \mathrm{O}\right)(8.6,17.2$ and $25.8 \mathrm{mg} / \mathrm{l})$ and copper sulfate $\left(\mathrm{CuSO}_{4} 5 \mathrm{H} 2 \mathrm{O}\right)(0.025,0.050,0.075 \mathrm{mg} / \mathrm{l})$ were added into nutrient medium of embryogenic callus stage. The results illustrated that, addtion of manganese sulfate at ( 22.3 $\mathrm{mg} / \mathrm{l}$ ) to culture medium of embryonic callus of Bartamoda $\mathrm{cv}$. gave the highest significant values of total free amino acids ( $1.75 \mathrm{mg} / \mathrm{g}$ fresh weight) and $(0.33 \mathrm{mg} / \mathrm{g}$ fresh weight) of total indols. Where the addition of manganese sulfate at $(66.9 \mathrm{mg} / \mathrm{l})$ to nuutrient medium of growing embryogenic callus of Bartamuda cv. gave the highest significant value of total phenols (1.17 $\mathrm{mg} / \mathrm{g}$ fresh weight). The addititon of zinc sulfate at $(17.2 \mathrm{mg} / \mathrm{l})$ to culture medium of embryogenic callus of Sakkoty cv., recorded the highest significant values of total amino acids (1.64 mg/g fresh weight) and Indoles( $0.40 \mathrm{mg} / \mathrm{g}$ fresh weight). While the highest significant values of total phenol content was $(1.24 \mathrm{mg} / \mathrm{g}$ fresh weight) when embryonic callus of Sakkoty cv. grown on medium contained zinc sulfate at $(25.8 \mathrm{mg} / \mathrm{l})$. Data showed also the highest significant values of total free amino acids and total indols content $(1.36$ and $0.40 \mathrm{mg} / \mathrm{g}$ fresh weight respectively) were achived when embryogenic callus of Bartamuda cv. was grown on medium containing of copper sulfate at $(0.025 \mathrm{mg} / \mathrm{l})$, wherase the highest significant value of total phenols content (1.83 mg/g fresh weight) were recorded when embryonic callus of Sakkoty cv. was grown on nutrient medium supplemented with copper sulfate at $(0.075 \mathrm{mg} / \mathrm{l})$.
\end{abstract}

\section{Introduction}

Date palm has indispensable utilization in the economy and domestic life of growing countries. It is considered one of the most important commercial crops in the Middle East and Arab World [1].

Secondary metabolites are considered as chemicals that are produced by plants and these chemicals are diverse, Identification of them made into many classes. Each species or plant family has its own mixture of secondary metabolites and that's considered a main advantage in classification of plants. These chemicals could be used for medicinal purposes for humans [2]. Date palms can accumulate many chemicals in their tissues, as a primary metabolites containing carbohydrates and proteins, and secondary metabolites which are produced from primary ones 
such as phenolics [3].Secondary metabolite production can be induced by medium optimizations $[4,5]$. Microelements have many diverse roles and they are required in trace amounts for plant growth and development [6]. Culture conditions play an important role in the quality and quantity of the material obtained through secondary metabolites [7]. Optimization of the culture condition is effective in improving the accumulation of the desired product. External factors such as carbon source, nitrogen source, growth regulators, medium $\mathrm{pH}$, temperature, light and oxygen are considered easy to regulate the expressions of plant secondary metabolite pathways [8]. Constituents in plant cell culture medium are determinants of growth and production of secondary metabolites. The specific roles for essential micronutrients in the production of active principles is due to their function as components or activators of enzymes of the secondary metabolism. Moreover, metals can quelate certain phytochemicals in plant tissues [9]. The aim of this work is to study the effect of microelements on production of (free amino acids, total indols content and total phenols content) in embryogenic callus stage of in vitro date palm (Bartamuda and Sakkoty cultivar).

\section{Materials and Methods}

Callus explants of tow cultivars Bartamuda and Sakkoty were produced from indirect protocol of date palm micropropagation discribed by [10,11].

In this study recived embryonic callus explants for both cultivars were cultured on basic nutrient medium for callus formation which composed of MS basal medium [12], supplemented $30 \mathrm{~g} / \mathrm{l}$ sucrose and $3.0 \mathrm{~g} / \mathrm{l}$ activated charcoal with $40 \mathrm{mg} / \mathrm{L}$ adenine - sulfate , 200

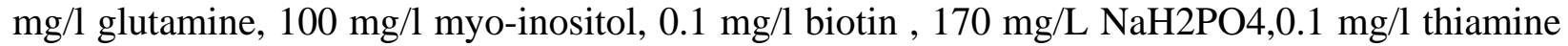
HCL $0.5 \mathrm{mg} / \mathrm{l}$ pyridoxine, $0.5 \mathrm{mg} / \mathrm{l}$ nicotinic acid, $3.0 \mathrm{mg} / \mathrm{L}$ 2- isopentenyl adenine (2iP) + 10.0 $\mathrm{mg} / \mathrm{l}$ 2,4 -D dichlorophenoxy acetic acid (2,4 - D).

Micro elements compounds, Manganese sulfate (MnSO4.4H2O), Zinc sulfate Heptahydrate ( $\mathrm{ZnSO} 4.7 \mathrm{H} 2 \mathrm{O})$ and Cupric Sulfate (CuSO4.5H2O) were added to previous basic nutrient medium for both Bartamuda and Sakkoty cv. callus cultures, in three different separated treatments for each as follows:-

1-Manganese sulfate (MnSO4.4H2O) were added at (22.3, 44.6 and $66.9 \mathrm{mg} / \mathrm{l}$ )

2- Zinc sulfate Heptahydrate (ZnSO4.7H2O) were added at ( $8.6,17.2$ and $25.8 \mathrm{mg} / \mathrm{l}$ )

3- Cupric Sulfate (CuSO4.5H2O) were added at $(0.025,0.050$ and $0.075 \mathrm{mg} / \mathrm{l})$ $6.0 \mathrm{~g} / \mathrm{L}$ agar were used to solidified Culture medium which were distributed in culture jars (250 $\mathrm{ml}$ ); each jar contained $25 \mathrm{ml}$ of culture nutrient medium. Culture jars were immediately capped with polypropylene closure autoclaved at 121_C at $1.05 \mathrm{~kg} / \mathrm{cm} 2$ for $20 \mathrm{~min}$. The cultured jars were incubated under total darkness at $27 \pm 1 \_\mathrm{C}$ and data were recorded every (6 weeks) for three subcultures on total steroids content ( $\mathrm{mg} / \mathrm{g}$ dry weight).

Callus sampels were collected from all studied treatments of the micro elements compounds, Manganese sulfate (MnSO4.4H2O), Zinc sulfate Heptahydrate (ZnSO4.7H2O) and Cupric Sulfate (CuSO4.5H2O) for both Bartamuda and Sakkoty cv. for the following assay

\section{Determination of free amino acids}

Total amino nitrogen or free amino acids were determined according to Rosein [13]. For assay, one $\mathrm{ml}$ of sample was pipetted out into a series of test tubes, and then total volume made up to 4 $\mathrm{ml}$ with distilled water. One $\mathrm{ml}$ of ninhydrin reagent $(4 \%, 4 \mathrm{~g}$ ninhydrin was dissolved in $50 \mathrm{ml}$ acetone and $50 \mathrm{ml}$ acetate buffer) was added to each tube, mixed well, and the tubes were kept in a boiling water bath for $15 \mathrm{~min}$. Then, the tubes were cooled and the volume was made up to 10 $\mathrm{ml}$ in measuring flask with ethanol $50 \%$. The pink color developed was measured using a 
spectrophotometer at $570 \mathrm{~nm}$ DL-alanine. The concentration of total amino nitrogen as DLalanine were calculated from the standard curve.

\section{Extraction of Indoles and Phenols}

One gram of fresh samples in three replicates were sectioned into minute pieces and extracted with $5 \mathrm{ml}$ cold methanol $80 \%$ and stored in cold condition for 24h. The combined extracts were collected and filtered. Then, the volume of sample was raised up to known volume with cold methanol.

\section{A Determination of Total Indoles}

The total indoles were determined in the methanolic extract using p-dimethyl amino benzaldehyde (PDAB) reagent, $1 \mathrm{~g}$ was dissolved in $50 \mathrm{ml} \mathrm{HCl}$ conc. and $50 \mathrm{ml}$ ethanol $95 \%$ ) test according to Larsen et al., [14]. One ml of aliquot methanolic extract was pipetted into a test tube, then $4 \mathrm{ml}$ of PDAB reagent was added and incubated at $30-40{ }^{\circ} \mathrm{C}$ for $1 \mathrm{~h}$. The intensity of the resultant color was spectrophotometerically measured at $530 \mathrm{~nm}$. A standard curve was established which refer to the relationship between different concentrations of IAA and their corresponding absorbance values.

\section{B Determination of Total Phenols}

Phenols determination was carried out according to Danial and George [15]. For estimation of total phenols, $1 \mathrm{ml}$ of the methanol tissue extract was added to $0.5 \mathrm{ml}$ of Folin-Ciocalteu's Phenol Reagent and shaken $3 \mathrm{~min}$. Then, $1 \mathrm{ml}$ saturated Na2CO3 (25\% w/v) plus $17.5 \mathrm{ml}$ distilled water added. The mixtures were left for one hour at $30-40{ }^{\circ} \mathrm{C}$. Optical density of these samples was measured by a colorimeter using wavelength $730 \mathrm{~nm}$. Concentrations of total phenols in different samples were calculated as $\mathrm{mg}$ phenol/100g FW. Amount of total phenolic compounds was calculated according to standard curve of pyrogalol (99.5 \%).

\section{Statistical analysis}

The obtained data were subjected to analysis of variance. The mean values were compared using LSD test at the $5 \%$ level of probability. The data were tabulated and statistically factorial analysed according to the randomized complete block design with three replicates Snedecor \& Cochran [16].

\section{Results and Discussion}

Effect of manganese sulfate (MnSO4.4H2O) concentration on some chemical component (total of amino acids, Indoles and Phenols) in embryogeinic callus stage of in vitro date palm (Sakkoty and Bartamuda cultivar)

\section{Effect of manganese sulfate on total amino acids content (mg/g fresh weight)}

Data in Table (1) clearly showed that no significant differences were found between the two cultivars under investigation $(0.90,0.90 \mathrm{mg} / \mathrm{g}$ fresh weight), was for Bartamuda and Sakkoty respectively. The manganese sulfate concentration $22.3 \mathrm{mg} / \mathrm{l}$ was the most effective forming the highest significant value (1.73 $\mathrm{mg} / \mathrm{g}$ fresh weight).Concerning the interaction between cultivars and manganese sulfate concentrations, the results illustrated that the highest significant value (1.75 mg/g fresh weight) was for Bartamuda cultivar embryogenic callus grown on medium contained $22.3 \mathrm{mg} / \mathrm{l}$ manganese sulfate. The lowest value $(0.29 \mathrm{mg} / \mathrm{g}$ fresh weight $)$ was for Bartamuda cultivar embryogenic callus grown on medium contained $66.9 \mathrm{mg} / \mathrm{l}$. 
Table 1: Effect of manganese sulfate on total amino acids content ( $\mathrm{mg} / \mathrm{g}$ fresh weight).

\begin{tabular}{|c|c|c|c|c|}
\hline \multirow{2}{*}{ Cultivar (A) } & \multicolumn{4}{|c|}{ Manganese sulfate mg/ I (B) } \\
\cline { 2 - 5 } & $\mathbf{2 2 . 3}$ & $\mathbf{4 4 . 6}$ & $\mathbf{6 6 . 9}$ & Mean (A) \\
\hline Bartamuda & 1.75 & 0.67 & 0.29 & 0.90 \\
\hline Sakkoty & 1.71 & 0.58 & 0.42 & 0.90 \\
\hline Mean (B) & 1.73 & 0.62 & 0.35 & \\
\hline L.S.D 0.05: A=N.S, B $=0.30, \mathrm{AB}=0.43$ \\
\hline
\end{tabular}

\section{Effect of manganese sulfate on total indoles content (mg/g fresh weight)}

Table 2: Effect of manganese sulfate on total indoles content ( $\mathrm{mg} / \mathrm{g}$ fresh weight).

\begin{tabular}{|c|c|c|c|c|}
\hline \multirow{2}{*}{ Cultivar(A) } & \multicolumn{4}{|c|}{ Manganese sulfate mg/ I (B) } \\
\cline { 2 - 5 } & $\mathbf{2 2 . 3}$ & $\mathbf{4 4 . 6}$ & $\mathbf{6 6 . 9}$ & Mean (A) \\
\hline Bartamuda & 0.33 & 0.16 & 0.15 & 0.21 \\
\hline Sakkoty & 0.29 & 0.13 & 0.08 & 0.16 \\
\hline Mean (B) & 0.31 & 0.15 & 0.11 & \\
\hline L.S.D 0.05: A $=0.046, \mathrm{~B}=0.057, \mathrm{AB}=0.081$ \\
\hline
\end{tabular}

Data in Table (2) clearly showed that significant differences were observed between the two cultivars under investigation (0.21, $0.16 \mathrm{mg} / \mathrm{g}$ fresh weight, Bartamuda ,Sakkoty respectively), the manganese sulfate concentration $22.3 \mathrm{mgll}$ was the most effective, forming the highest significant value $(0.31 \mathrm{mg} / \mathrm{g}$ fresh weight),concerning the interaction between cultivars and manganese sulfate concentrations, the results illustrated that the highest significant value $(0.33$ $\mathrm{mg} / \mathrm{g}$ fresh weight) was recorded by Bartamuda cultivar embryogenic callus which was grown on medium contained $22.3 \mathrm{mg} / \mathrm{l}$ manganese sulfate. The lowest value $(0.08 \mathrm{mg} / \mathrm{g}$ fresh weight) was for Sakkoty cultivar embryogenic callus grown on medium contained $66.9 \mathrm{mg} / \mathrm{l}$.

\section{Effect of manganese sulfate on total phenols content (mg/g fresh weight)}

Table 3: Effect of manganese sulfate on total phenols content ( $\mathrm{mg} / \mathrm{g}$ fresh weight).

\begin{tabular}{|c|c|c|c|c|}
\hline \multirow{2}{*}{ Cultivar (A) } & \multicolumn{4}{|c|}{ Manganese sulfate mg/ I (B) } \\
\cline { 2 - 5 } & $\mathbf{2 2 . 3}$ & $\mathbf{4 4 . 6}$ & $\mathbf{6 6 . 9}$ & Mean (A) \\
\hline Bartamuda & 0.48 & 0.80 & 1.17 & 0.82 \\
\hline Sakkoty & 0.37 & 0.83 & 1.07 & 0.76 \\
\hline Mean (B) & 0.42 & 0.82 & 1.12 & \\
\hline \multicolumn{5}{|c|}{ L.S.D 0.05, A=N.S, B $=0.13, \mathrm{AB}=0.19$} \\
\hline
\end{tabular}

Data in Table (3) clearly showed that no significant differences were found between the two cultivars under investigation (0.82, $0.76 \mathrm{mg} / \mathrm{g}$ fresh weight, Bartamuda, Sakkoty respectively).The manganese sulfate concentration $66.9 \mathrm{mg} / \mathrm{l}$ was the most effective. The highest significant value (1.12 $\mathrm{mg} / \mathrm{g}$ fresh weight), concerning the interaction between cultivars and manganese sulfate concentrations, the highest significant value $(1.17 \mathrm{mg} / \mathrm{g}$ fresh weight) was for 
Bartamuda cultivar embryogenic callus grown on medium contained $66.9 \mathrm{mg} / \mathrm{l}$ manganese sulfate. The lowest value $(0.37 \mathrm{mg} / \mathrm{g}$ fresh weight) was for Sakkoty cultivar embryogenic callus grown on medium contained $22.3 \mathrm{mg} / \mathrm{l}$.

Effect of Zinc sulfate Heptahydrate (ZnSO4.7H2O) concentration on some chemical component (total of amino acids, Indoles and Phenols) in embryogeinic callus stage of in vitro date palm (Sakkoty and Bartamuda cultivar)

\section{Effect of zinc sulfate on the total amino acid content ( $\mathrm{mg} / \mathrm{g}$ fresh weight)}

Table 4: Effect of zinc sulfate on total amino acid content ( $\mathrm{mg} / \mathrm{g}$ fresh weight).

\begin{tabular}{|c|c|c|c|c|}
\hline \multirow{2}{*}{ Cultivar (A) } & \multicolumn{4}{|c|}{ zinc sulfate mg/ I (B) } \\
\cline { 2 - 5 } & $\mathbf{8 . 6}$ & $\mathbf{1 7 . 2}$ & $\mathbf{2 5 . 8}$ & Mean (A) \\
\hline Bartamuda & 0.77 & 1.63 & 0.42 & 0.94 \\
\hline Sakkoty & 0.57 & 1.64 & 0.36 & 0.86 \\
\hline Mean (B) & 0.67 & 1.64 & 0.39 & \\
\hline \multicolumn{5}{|c|}{ L.S.D 0.05: A=N.S, B=0.30, AB=0.43 } \\
\hline
\end{tabular}

Data in Table (4) showed that, no significant differences were noticed between the two cultivars under investigation $(0.94,0.86 \mathrm{mg} / \mathrm{g}$ fresh weight respectively) zinc sulfate concentration $17.2 \mathrm{mg} / \mathrm{l}$ was the most effective as it induced, the highest significant value was(1.64 mg/g fresh weight), concerning the interaction between cultivars and zinc sulfate concentrations, the highest significant value $(1.64 \mathrm{mg} / \mathrm{g}$ fresh weight) was produced by for Sakkoty cultivar embryogenic callus grown on medium contained $17.2 \mathrm{mg} / \mathrm{l}$ zinc sulfate. The lowest value $(0.36 \mathrm{mg} / \mathrm{g}$ fresh weight) was for Sakkoty cultivar embryogenic callus grown on medium contained $25.8 \mathrm{mg} / \mathrm{l}$ zinc sulfate.

\section{Effect of zinc sulfate on the total indoles content (mg/g fresh weight)}

Table 5: Effect of zinc sulfate on total indoles content ( $\mathrm{mg} / \mathrm{g}$ fresh weight).

\begin{tabular}{|c|c|c|c|c|}
\hline \multirow{2}{*}{ Cultivar (A) } & \multicolumn{4}{|c|}{ zinc sulfate $\mathbf{~ m g / ~ I ~ ( B ) ~}$} \\
\cline { 2 - 5 } & $\mathbf{8 . 6}$ & $\mathbf{1 7 . 2}$ & $\mathbf{2 5 . 8}$ & Mean (A) \\
\hline Bartamuda & 0.076 & 0.376 & 0.113 & 0.188 \\
\hline Sakkoty & 0.090 & 0.400 & 0.133 & 0.207 \\
\hline Mean (B) & 0.083 & 0.388 & 0.123 & \\
\hline \multicolumn{5}{|c|}{ L.S.D 0.05: A=N.S, B=0.070, AB $=0.099$} \\
\hline
\end{tabular}

Data in Table (5) showed that no significant differences were formed between the two cultivars under investigation $(0.18,0.20 \mathrm{mg} / \mathrm{g}$ fresh weight respectively), zinc sulfate concentration(17.2mg/l) was the most effective as it produced ,the highest significant value was $(0.38 \mathrm{mg} / \mathrm{g}$ fresh weight), concerning the interaction between cultivars and zinc sulfate concentrations, the highest significant value $(0.40 \mathrm{mg} / \mathrm{g}$ fresh weight) was for Sakkoty cultivar 
embryogenic callus grown on medium contained( $17.2 \mathrm{mg} / \mathrm{l})$ zinc sulfate. The lowest value (0.076 mg/g fresh weight) was for Bartamuda cultivar embryogenic callus grown on medium contained $(8.6 \mathrm{mg} / \mathrm{l})$ zinc sulfate.

\section{Effect of zinc sulfate on the total phenols content (mg/g fresh weight)}

Table 6: Effect of zinc sulfate on the total phenols content ( $\mathrm{mg} / \mathrm{g}$ fresh weight).

\begin{tabular}{|c|c|c|c|c|}
\hline \multirow{2}{*}{ Cultivar (A) } & \multicolumn{4}{|c|}{ zinc sulfate mg/ I (B) } \\
\cline { 2 - 5 } & $\mathbf{8 . 6}$ & $\mathbf{1 7 . 2}$ & $\mathbf{2 5 . 8}$ & Mean (A) \\
\hline Bartamuda & 0.81 & 0.31 & 1.20 & 0.78 \\
\hline Sakkoty & 0.66 & 0.44 & 1.24 & 0.78 \\
\hline Mean (B) & 0.73 & 0.38 & 1.22 & \\
\hline L.S.D 0.05: A=N.S, B=0.22, AB=0.31 \\
\hline
\end{tabular}

Data in Table (6) showed that no significant differences were formed between the two cultivars under investigation $(0.78,0.78 \mathrm{mg} / \mathrm{g}$ fresh weight respectively), zinc sulfate concentration $25.8 \mathrm{mg} / \mathrm{l}$ was the most effective as it induced, the highest significant value was (1.22 $\mathrm{mg} / \mathrm{g}$ fresh weight), concerning the interaction between cultivars and zinc sulfate concentrations, the highest significant value $(1.24 \mathrm{mg} / \mathrm{g}$ fresh weight) was for Sakkoty cultivar embryogenic callus grown on medium contained $25.8 \mathrm{mg} / \mathrm{l}$ zinc sulfate. The lowest value $(0.31$ $\mathrm{mg} / \mathrm{g}$ fresh weight) was for Bartamuda cultivar embryogenic callus grown on medium contained $17.2 \mathrm{mg} / \mathrm{l}$ zinc sulfate.

Effect of Cupric Sulfate (CuSO4.5H2O) concentration on some chemical component (total of amino acids, Indoles and Phenols) in embryogeinic callus stage of in vitro date palm (Sakkoty and Bartamuda cultivar)

\section{Effect of cupric sulfate on total amino acids content (mg/g fresh weight)}

Table 7: Effect of cupric sulfate on total amino acids content (mg/g fresh weight).

\begin{tabular}{|c|c|c|c|c|}
\hline \multirow{2}{*}{ Cultivar (A) } & \multicolumn{4}{|c|}{ cupric sulfate mg/l (B) } \\
\cline { 2 - 5 } & $\mathbf{0 . 0 2 5}$ & $\mathbf{0 . 0 5 0}$ & $\mathbf{0 . 0 7 5}$ & Mean (A) \\
\hline Bartamuda & 1.36 & 0.61 & 0.30 & 0.75 \\
\hline Sakkoty & 1.14 & 0.84 & 0.31 & 0.76 \\
\hline Mean (B) & 1.25 & 0.72 & 0.31 & \\
\hline \multicolumn{5}{|c|}{ L.S.D 0.05: A=N.S, B=0.11, AB= 0.16} \\
\hline
\end{tabular}

Data in Table (7) showed that no significant differences were found between the two cultivars under investigation $(0.75,0.76 \mathrm{mg} / \mathrm{g}$ fresh weight respectively),cupric sulfate concentration $0.025 \mathrm{mg} / \mathrm{l}$ was the most effective as it induced, the highest significant value $(1.25 \mathrm{mg} / \mathrm{g}$ fresh weight), concerning the interaction between cultivars and cupric sulfate concentrations, the highest significant value (1.36 mg/g fresh weight) was for Bartamuda cultivar embryogenic callus grown on medium contained $0.025 \mathrm{mg} / \mathrm{l}$ cupric sulfate. The lowest value $(0.30 \mathrm{mg} / \mathrm{g}$ fresh weight) was for Bartamuda cultivar embryogenic callus grown on medium contained $0.075 \mathrm{mg} / \mathrm{l}$ cupric sulfate. 


\section{Effect of cupric sulfate on total indoles content (mg/g fresh weight)}

Table 8: Effect of cupric sulfate on total indoles content ( $\mathrm{mg} / \mathrm{g}$ fresh weight).

\begin{tabular}{|c|c|c|c|c|}
\hline \multirow{2}{*}{ Cultivar (A) } & \multicolumn{4}{|c|}{ cupric sulfate mg/l (B) } \\
\cline { 2 - 5 } & $\mathbf{0 . 0 2 5}$ & $\mathbf{0 . 0 5 0}$ & $\mathbf{0 . 0 7 5}$ & Mean (A) \\
\hline Bartamuda & 0.40 & 0.16 & 0.09 & 0.22 \\
\hline Sakkoty & 0.25 & 0.11 & 0.07 & 0.14 \\
\hline Mean (B) & 0.32 & 0.14 & 0.08 & \\
\hline L.S.D 0.05: A=0.033, B $=0.040, \mathrm{AB}=0.057$ \\
\hline
\end{tabular}

Data in Table (8) showed that, significant differences were found between the two cultivars under investigation $(0.22,0.14 \mathrm{mg} / \mathrm{g}$ fresh weight respectively),cupric sulfate concentration $0.025 \mathrm{mg} / \mathrm{l}$ was the most effective as it produced the highest significant value $(0.32 \mathrm{mg} / \mathrm{g}$ fresh weight), concerning the interaction between cultivars and cupric sulfate concentrations, the highest significant value $(0.40 \mathrm{mg} / \mathrm{g}$ fresh weight) was for Bartamuda cultivar embryogenic callus grown on medium contained $0.025 \mathrm{mg} / \mathrm{l}$ cupric sulfate. The lowest value $(0.07 \mathrm{mg} / \mathrm{g}$ fresh weight) was for Sakkoty cultivar embryogenic callus grown on medium contained $0.075 \mathrm{mg} / \mathrm{l}$ cupric sulfate.

\section{Effect of cupric sulfate on total phenols content (mg/g fresh weight)}

Table 9: Effect of cupric sulfate on total phenols content ( $\mathrm{mg} / \mathrm{g}$ fresh weight).

\begin{tabular}{|c|c|c|c|c|}
\hline \multirow{2}{*}{ Cultivar (A) } & \multicolumn{5}{|c|}{ cupric sulfate (CuSO4.5H2O)mg/l (B) } \\
\cline { 2 - 5 } & $\mathbf{0 . 0 2 5}$ & $\mathbf{0 . 0 5 0}$ & $\mathbf{0 . 0 7 5}$ & Mean (A) \\
\hline Bartamuda & 0.34 & 1.28 & 1.53 & 1.05 \\
\hline Sakkoty & 0.47 & 1.56 & 1.83 & 1.28 \\
\hline Mean (B) & 0.41 & 1.04 & 1.68 & \\
\hline \multicolumn{4}{|c|}{ L.S.D 0.05: A $=0.18, \mathrm{~B}=0.23, \mathrm{AB}=0.32$} \\
\hline
\end{tabular}

Data in Table (9) clearly showed that, significant differences were found between the two cultivars under investigation (1.05, $1.28 \mathrm{mg} / \mathrm{g}$ fresh weight respectively), cupric sulfate concentration $0.075 \mathrm{mg} / \mathrm{l}$ was the most effective as it produced the highest significant value was (1.68 $\mathrm{mg} / \mathrm{g}$ fresh weight), concerning the interaction between cultivars and cupric sulfate concentrations, the highest significant value $(1.83 \mathrm{mg} / \mathrm{g}$ fresh weight) was for Sakkoty cultivar embryogenic callus grown on medium contained $0.075 \mathrm{mg} / \mathrm{l}$ cupric sulfate. The lowest value (0.34 mg/g fresh weight) was recorded by Bartamuda cultivar embryogenic callus grown on medium contained $0.025 \mathrm{mg} / \mathrm{l}$ cupric sulfate.

The present results regarding the beneficial effect of manganese sulfate (MnSO4.4H2O) zinc sulfate (ZnSO4.7H2O) and cupric sulfate (CuSO4.5H2O) as microelements in congeniality with the findings of several investigators on some species. Plant-produced secondary compounds have been contributed into a wide range of commercial and manufactories applications. Obviously, in many cases, rigorously controlled plant in vitro cultures can generate the same valuable natural 
products [7]. There are many studies made on the method that could be used for the enhancement of the production of valuable secondary metabolites. Microelements are required in trace amounts (Manganese, iodine, copper, cobalt, boron, molybdenum, iron, and zinc) usually comprise the microelements for plant growth and development, and have many diverse roles The effects of the medium employed in various processes have been reported [8]. It has been reported that proper concentration microelements have been considered as nutrient factors or as abiotic elicitors, which trigger the formation of secondary metabolites [9]. Where, Metal ions cause stress at elevated concentrations and stress has been implicated in secondary metabolite production. Many studies were undertaken to assess the role of metal stress on growth and differentiation as well as on secondary metabolite production in plants [17]. Copper, for example, is essential for the function of many oxidases and oxygenases with a key role in secondary metabolism. Also, Copper deficiency strongly inhibits the activities of diamine oxidase, which is essential for the metabolism of the diamines putrescine and cadaverine of polyphenoloxidase, and of superoxide dismutase (Cu/ZnSOD) Micronutrients without redox functions are also directly or indirectly involved in plant secondary metabolism. Zinc is required for the activity of thousands of plant proteins. Manganese is essential for Mn-SOD activity. In the shikimate pathway, Mn stimulates the pre-chorismate step catalyzed by the metalloenzyme 3deoxy-D-arabinoheptulosonate 7-phosphate synthase [9]. It could be suggested that the production of preformed phytochemicals can also be significantly enhanced by those, trace elements which are being widely used to stimulate the production of active principles from callus cultures.

\section{Summary}

Studies in this area could lead to the successful manipulation of secondary metabolism and could significantly increase the amounts of the compounds. It should be possible to achieve the synthesis of a wide range of compounds in date palm callus cultures.

\section{References}

[1] S. Gantait, M.M. El-Dawayati, J. Panigrahi, C. Labrooy, S.K. Verma, The retrospect and prospect of the applications of biotechnology in ( Phoenix dactylifera L.), App. Microbial. Biotech. 102 (2018) 8229-8259. https://doi.org/10.1007/s00253-018-9232-x

[2] E. Ahmed, M. Arshad, M.Z. Khan, Secondary metabolites and their multidimensional prospective in plant life, J. Pharm. Phyto. 2 (2017) 205-14.

[3] R. Al-Alawi, J. Al-Mashiqri, J. Al-Nadabi, B. Al-Shihi, Y. Baq, Date palm tree (Phoenix dactylifera L.) natural products and therapeutic options, Front Plant Sci. 8 (2017) 1-12. https://doi.org/10.3389/fpls.2017.00845

[4] M.I. Dias, M.J. Sousa, R.C. Alves, I.C. Ferreira, Exploring plant tissue culture to improve the production of phenolic compounds: A review, Industrial Crops and Products, 1-82 (2016) 9-22. https://doi.org/10.1016/j.indcrop.2015.12.016

[5] I. Smetanska, Production of secondary metabolites using plant cell cultures, In Food biotech Springer, Berlin, Heidelberg, (2008) 187-228.

[6] W. Yue, Q.L. Ming, B. Lin, K. Rahman, C.J. Zheng, T. Han, L.P. Qin, Medicinal plant cell suspension cultures: pharmaceutical applications and high-yielding strategies for the desired 
secondary metabolites, Critical reviews in biotechnology 36-2 (2016) 215-32. https://doi.org/10.3109/07388551.2014.923986

[7] N.A. Fadzliana, S. Rogayah, N.A. Shaharuddin, O.A. Janna, Addition of L-Tyrosine to Improve Betalain Production in Red Pitaya Callus, Pertanika J. Tropical Agr. Sci. 40-4 (2017) 521-532.

[8] I. Smetanska, Production of secondary metabolites using plant cell cultures, In Food biotech Springer, Berlin, Heidelberg (2008) 187-228.

[9] C. Poschenrieder, J. Allué, R. Tolrà, M. Llugany, J. Barceló, Trace Elements and Plants Secondary Metabolism: Quality and Efficacy of Herbal Products. Trace Elements as Contaminants and Nutrients/ed. by MNV Prasad Published by John Wiley \& Sons, Inc., Hoboken, New Jersey 25 (2008) 99-120. https://doi.org/10.1002/9780470370124.ch5

[10] Z.E., Zayed, Enhanced Indirect Somatic Embryogenesis from Shoot-Tip Explants of Date Palm by Gradual Reductions of 2, 4-D Concentration, In Date Palm Biotechnology Protocols, Humana Press, New York, 1 (2017) 77-88. https://doi.org/10.1007/978-1-4939-7156-5_7

[11] M.M. El-Dawayati, H.S. Ghazzawy, M. Munir, Somatic embryogenesis enhancement of date palm cultivar Sewi using different types of polyamines and glutamine amino acid concentration under in-vitro solid and liquid media conditions, Int J Biosci 12 (2018) 149-159. https://doi.org/10.12692/ijb/12.1.149-159

[12] T. Murashige, F. Skoog, A revised medium for rapid growth and bioassays with tobacco tissue cultures, Physiol. Plant 15 (1962) 473-497. https://doi.org/10.1111/j.13993054.1962.tb08052.x

[13] Rosein, H., A modified ninhydrin coloremetric analysis for amino acids, Archives of Biochemistry and Biophysics, 67 (1957) 10-15. https://doi.org/10.1016/0003-9861(57)90241-2

[14] P. Larsen, A. Harbo, S. Klungsour, T. Asheim, On the biogenesis of some indol compounds in Acetobacter xylinum. Physiologia Plantarum, 15 (1962) 552-655.

https://doi.org/10.1111/j.1399-3054.1962.tb08058.x

[15] H.D. Danial, C.M. George, Peach seed dormancy in relation to endogenous inhibitors and applied growth substances, Journal of the American Society for Horticultural Science 17 (1972) 651- 654.

[16] G.W. Snedecor, W.G. Cochran, Statisical Methods, Oxford and J.B.H. Publishing Co., 6th edition, 1980, pp. 507.

[17] H. Gaosheng, J. Jingming, Production of Useful Secondary Metabolites Through Regulation of Biosynthetic Pathway in Cell and Tissue Suspension Culture of Medicinal Plants, Recent Advances in Plant in vitro Culture, Annarita Leva and Laura M. R. Rinaldi, IntechOpen, (2012). https://doi.org/10.5772/53038 